\title{
AXON REFLEX SWEATING IN RHEUMATOID ARTHRITIS
}

BY

\author{
J. L. KALLIOMÄKI, H. A. SAARIMAA, AND P. TOIVANEN \\ From the Department of Medicine, University of Turku, Finland
}

In an axon reflex, impulses are conveyed from the points of stimulation centripetally through branches of ramifying axons and again centrifugally (without any interpolated cell in its path) to the effector organs (Collins and Weiner, 1961). The arteriolar flare produced by injury or by the action of histamine, the pilomotor reaction to faradic stimulation, and the sweating produced by faradic stimulation in the vicinity of electrodes are examples of this axon reflex mechanism.

The local sweating response produced by intradermal injection of nicotine has also been demonstrated to be mediated through the local reflex arc (Coon and Rothman, 1941). The axon reflex function in rheumatoid arthritis has not, so far as we know, been studied earlier. However, many signs exist in rheumatoid arthritis (cold clammy hands; "liver hands"; dark discoloration of dorsal skin of finger joints; Raynaud's syndrome, etc.), the pathogenesis of which is obscure. This paper reports our observations on axon reflex sweating produced by nicotine in rheumatoid arthritis, with special reference to the correlation between this nicotine sweat response and some of the clinical signs of rheumatoid arthritis.

\section{Material}

Rheumatoid Arthritis. -100 consecutive cases $(70$ women, 30 men; mean age 47.9 years) treated in the Out-Patient Department for Rheumatoid Arthritis in the Central Hospital, University of Turku.

Control Series. -100 patients (44 women, 56 men; mean age $51 \cdot 1$ years) with no somatic disease, treated at a psychiatric ward for mental disorders.

\section{Methods}

The optimal axon reflex sweat reactions are usually obtained with a $10^{-5}$ concentration of nicotine in $0 \cdot 1 \mathrm{ml}$. (1 $\mu \mathrm{g}$.) (Collins and Weiner, 1961). We injected this amount and concentration of nicotine intradermally, always into the same area of the volar side of forearm. The sweat response was demonstrated after 45 seconds, using the iodine-starch paper method (Dole and Thaysen 1953). The diameter of the local sweating area was determined, and the response was graded as,,-+++ +++ . Examples of these recordings are presented is the Figure (opposite).

\section{Results}

Comparison between Rheumatoid and Control Groups

The nicotine sweat response in the rheumatoid and control series is shown in Table $\mathbf{I}$.

TABLE I

NICOTINE SWEAT RESPONSE

\begin{tabular}{|c|c|c|c|c|}
\hline Series & . & . & $\begin{array}{c}\text { Rheumatoid } \\
\text { Arthritis }\end{array}$ & Control \\
\hline No. of Cases & . & . & 100 & 100 \\
\hline Response & + & & $\begin{array}{r}4 \\
16 \\
33 \\
47\end{array}$ & $\begin{array}{l}18 \\
24 \\
32 \\
26\end{array}$ \\
\hline \multirow{2}{*}{\multicolumn{2}{|c|}{$\begin{array}{c}\text { Diameter of } \\
\text { Local Sweat } \\
\text { Response Area (mm.) }\end{array}$}} & Average & $14 \cdot 3$ & $23 \cdot 2$ \\
\hline & & Range & $0-45$ & $0-54$ \\
\hline
\end{tabular}

The number of patients reacting negatively in the axon reflex sweating test was significantly higher $(p<0.01)$ in the rheumatoid group than in the control group. It proved, however, that this difference was seen only between the women in the two groups. 

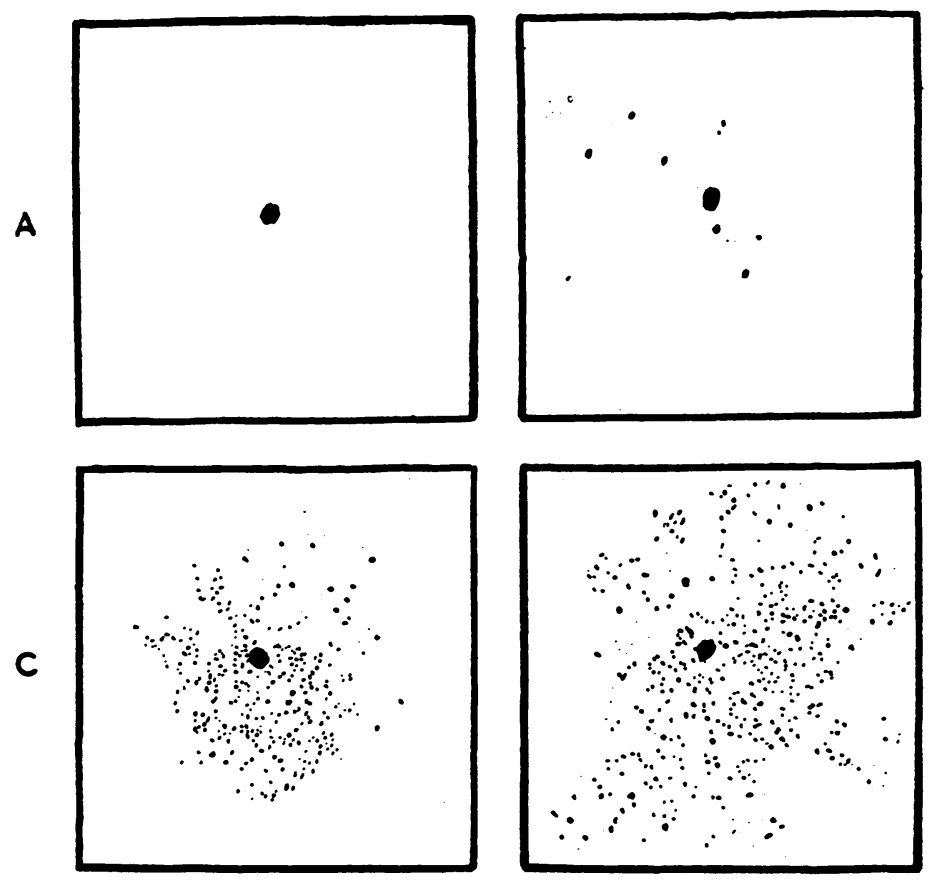

D

Figure.-Recording of responses in the axon reflex sweating test.

$$
\begin{aligned}
& \mathbf{A}=- \\
& \mathbf{B}=+ \\
& \mathbf{C}=++ \\
& \mathbf{D}=+++
\end{aligned}
$$

Table II shows that the difference between the women and men of the control group is not significant, but in the rheumatoid group the difference is significant $(p<0.001)$.

i.

\begin{tabular}{|c|c|c|c|c|c|c|c|}
\hline \multirow{2}{*}{$\begin{array}{l}\text { Series } \\
\text { Sex } \quad .\end{array}$} & \multirow{2}{*}{$\cdots$} & \multirow{2}{*}{$\cdots$} & \multirow{2}{*}{$\frac{\cdots}{\cdots}$} & \multicolumn{2}{|c|}{$\begin{array}{l}\text { Rheumatoid } \\
\text { Arthritis }\end{array}$} & \multicolumn{2}{|c|}{ Control } \\
\hline & & & & Women & Men & Women & Men \\
\hline \multicolumn{2}{|c|}{ Number of Cases } & . & .. & 70 & 30 & 44 & 56 \\
\hline \multicolumn{3}{|c|}{$\begin{array}{l}\text { Negative Axon Reflex } \\
\text { Sweating Test }\end{array}$} & & 40 & 7 & 12 & 14 \\
\hline
\end{tabular}

TABLE II

NICOTINE SWEAT RESPONSE, BY SEX

Comparison between Axon Reflex Sweating and Clinical Characteristics and Signs of Rheumatoid Arthritis

Duration of Disease.-The axon reflex sweating test was negative in $26(54 \pm 7 \cdot 2$ per cent.) of the 48 cases in which the rheumatoid arthritis had lasted $\geq 5$ years. Of the 52 cases in which the history was $<5$ years the axon reflex sweating test was negative in $21(40 \pm 6.8$ per cent. $)$. The difference is statistically insignificant $(t=1 \cdot 40)$.
Stage of Rheumatoid Arthritis.-59 of the rheumatoid arthritics belonged to Stages I-II, and 27 of these reacted negatively in the axon reflex sweating test. Of 41 patients in Stages III-IV, twenty gave a negative reaction, and there was thus no difference in this respect.

Erythrocyte Sedimentation Rate.-Of the 37 cases in which the erythrocyte sedimentation rate was $\geqq 40 \mathrm{~mm}$. $/ \mathrm{hr}$, the axon reflex sweating test was negative in 24 (65 \pm 7.9 per cent.). Of the 63 in which the erythrocyte sedimentation rate was $<40 \mathrm{~mm}$. $/ \mathrm{hr}$, the axon reflex sweating test was negative in 23 ( $37 \pm 6.1$ per cent.), and the difference is therefore statistically significant $(p<0.01)$.

Moisture of the Hands.-An abnormally strong moisture of the hands was observed in 28 cases, but this phenomenon had no correlation to the axon reflex sweating.

Coldness of the Hands. - Of 24 patients with very cold hands, seventeen gave a negative response in the axon reflex sweating test, but of the remaining 
76,31 reacted negatively, and the difference is therefore statistically significant $(p<0.05)$.

"Liver Hands".-This phenomenon was observed in 21 cases, eight of which had a negative response; in the remaining 79 cases 39 had a negative response. The difference between the groups is thus insignificant.

Dark Discoloration of the Dorsal Skin of the Finger Joints. - This sign was observed in eight cases without any correlation to the axon reflex sweating test.

Treatment and Diameter of Axon Reflex Sweating Response.-The groups presented in Table III are so small that the possible differences are insignificant.

TABLE III

NICOTINE SWEAT RESPONSE IN RHEUMATOID CASES, BY TREATMENT

\begin{tabular}{|c|c|c|c|}
\hline \multirow[t]{2}{*}{ Treatment } & \multirow{2}{*}{$\begin{array}{c}\text { Number } \\
\text { of } \\
\text { Cases }\end{array}$} & \multicolumn{2}{|c|}{$\begin{array}{c}\text { Diameter of Local } \\
\text { Sweat Response Area } \\
\text { (mm.) }\end{array}$} \\
\hline & & Range & Average \\
\hline $\begin{array}{l}\text { Antimalarials } \\
\text { Antimalarials }+ \text { phenylbutazone } \\
\text { Antimalarials }+ \text { gold salts } \\
\text { Antimalarials }+\underset{\text { gold salts and }}{\text { phenylbutazone }} \\
\begin{array}{l}\text { Only Gold Salts } \\
\text { Corticosteroids }+ \text { Some other } \\
\text { treatment }\end{array}\end{array}$ & $\begin{array}{r}13 \\
9 \\
27 \\
12 \\
17 \\
10\end{array}$ & $\begin{array}{l}0-36 \\
0-39 \\
0-44 \\
0-40 \\
0-45 \\
0-40\end{array}$ & $\begin{array}{r}9 \cdot 0 \\
7 \cdot 9 \\
16 \cdot 8 \\
13 \cdot 2 \\
15 \cdot 6 \\
21 \cdot 3\end{array}$ \\
\hline
\end{tabular}

\section{Discussion}

The physiological function of axon reflex sweating is still obscure. Collins and Weiner (1961) are of the opinion that there is no evidence that axon reflex sweating is concerned in normal thermogenic sweat response. Their studies do not support the earlier hypothesis of a sympathetic ganglion structure in the effector limb of the axon reflex pathway. There is, however, some evidence that the axon system is supplied by terminal fibres of the sympathetic nerves (Collins and Weiner, 1961).

Our observations suggest that axon reflex sweating is impaired in female rheumatoid arthritics. Differences between the reactions of men and women with rheumatoid arthritis have been observed, for example, in the adrenocortical secretion capacity (Pekkarinen and Kalliomäki, 1958). Whether women with an impaired axon reflex function have a stronger disposition to suffer from rheumatoid arthritis or whether this impaired axon reflex function is secondary to the disease is not known. The latter possibility is suggested by the (statistically insignificant) trend of the axon reflex sweating test to be negative more often in patients with a long duration of disease. It must also be borne in mind that peripheral neuropathy is not unusual in rheumatoid arthritis (Hart, Golding, and Mackenzie, 1957), and that axon reflex sweating may be lost through degeneration of the sympathetic neurones after sympathectomy (Bickford, 1938) and post-ganglionic sympathectomy (Coon and Rothman, 1941).

The correlation between cold hands and impaired axon reflex function recalls the theory that vasodilatation in the human forearm might be caused by the action of vasodilatator substances released from activated sweat glands (Grant and Holling, 1938; Love and Shanks, 1962). This hypothesis was substantiated by Fox and Hilton (1958) by isolating bradykinin-forming enzyme from sweat and finding increased bradykinin-like activity in perfusate from the subcutaneous tissue of the forearm during sweating. In an earlier report we have shown that the elevation of peripheral skin temperature by reserpine is more pronounced in patients with rheumatoid arthritis than in controls (Kalliomäki, Kärki, and Saarimaa, 1961).

It has been reported earlier that the nicotinic acies ester skin test ("Trafuril test") gives negative result in 70 per cent. of patients with rheumatoid arthritis while healthy controls react positively (Nassim and Banner, 1952; Oka, 1953). The negativity of this test is, however, not specific for rheumatoid arthritis, as it is also more often negative in patients with chronic azotaemia than in controls (Kalliomäki, Markkanen, and Toivanen, 1960). On the basis of the observations presented in this paper it is logical, we believe, to suppose that the dermal erythema which appears in the nicotinic acid ester skin test is also mediated through the axon reflex arc.

Our control series consisted of patients with mental disorders without somatic disease. This being the case, we cannot say whether the findings presented in this paper are specific for rheumatoid arthritis. The same findings might be observed, for example, in chronic azotaemia or other somatic diseases.

\section{Summary}

(1) The axon reflex sweating test has been per- $\widetilde{F}$ formed in 100 patients with rheumatoid arthritis 0

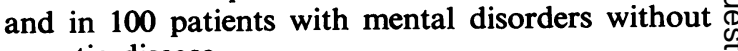
somatic disease.

(2) In the female rheumatoid arthritics the result of this test was more often negative than in the 
female controls. No significant difference was observed in the male cases.

(3) Cold hands and a high erythrocyte sedimentation rate often accompanied impaired axon reflex function.

\section{REFERENCES}

Bickford, R. G. (1938). Clin. Sci., 3, 337.

Collins, K. J., and Weiner, J. S. (1961). Ibid., 21, 333.

Coon, J. M., and Rothman, S. (1941). J. Pharmacol., $73,1$.

Dole, V. P., and Thaysen, J. H. (1953). J. exp. Med., 98, 129.

Fox, R. H., and Hilton, S. M. (1958). J. Physiol. (Lond.), 142, 219.

Grant, R. T., and Holling, H. E. (1938). Clin. Sci., 3, 273.

Hart, F. D., Golding, J. R., and Mackenzie, D. H. (1957). Ann. rheum. Dis., 16, 471.

Kalliomäki, J. L., Kärki, N. T., and Saarimaa, H. A. (1961). Arch. interamer. Rheum., 4, 320.

-, Markkanen, T. K., and Toivanen, P. (1960). Acta tuberc. scand., 38, 126.

Love, A. H. G., and Shanks, R. G. (1962). J. Physiol. (Lond.), 162, 121.

Nassim, J. R., and Banner, H. (1952). Lancet, 1, 699.

Oka, M. (1953). Acta med. scand., 145, 258.

Pekkarinen, A., and Kalliomäki, L. (1958). Acta endocrin. (Kbh.), 28, 417.
Sudation par reflexe d'axon dans l'arthrite rhumatismale

RÉSUMÉ

(1) Le test de sudation par reflexe de cylindre-axe fut effectué chez 100 malades atteints d'arthrite rhumatismale et chez 100 patients atteints de désordres mentaux mais ne souffrant pas de maladie organique.

(2) Chez des femmes atteintes d'arthrite rhumatismale le résultat de ce test fut négatif plus souvent que chez les témoins. On n'observa pas de différence parmi les hommes.

(3) Des mains froides et une vitesse de sédimentation érythrocytaire élévée accompagnaient souvent l'altération de la fonction du reflexe d'axon.

\section{Sudación por reflejo axonal en artritis reumatoide}

\section{Sumario}

(1) El test de sudación por reflejo axonal fué hecho en 100 enfermos con artritis reumatoide $y$ en 100 pacientes con disturbios mentales pero sin enfermedad orgánica.

(2) En mujeres con artritis reumatoide el resultado de este test fué negativo con más frecuencia que en testigos. No se observó diferencia entre los hombres.

(3) Manos frías y velocidad de sedimentación eritrocitaria aumentada acompañaron a menudo la función defectiva del reflejo axonal. 